\title{
Studies in the genus Riccia (Marchantiales) from southern Africa. 15. $R$. hirsuta and $R$. tomentosa, sp. nov., two distinct species previously treated as one
}

\author{
O.H. VOLK* and S.M. PEROLD**
}

Keywords: Marchantiales, Riccia hirsuta, R. tomentosa, section Pilifer, section Micantes, section Pannosae, southem Africa, subgenus Thallocarpus, taxonomy, tetrad spores

\section{ABSTRACT}

The description of Riccia hirsuta (Volk \& Perold 1986) is emended and new illustrations of the species are provided, as the original description and illustrations were based on two distinct, but rather similar species. Examination of newly collected material of $R$. hirsuta, showed it to belong to subgenus Riccia, section Pilifer (Volk 1983). Section Micantes (Volk \& Perold 1986) of which this was the type species, is therefore transferred to section Pilifer. $R$. tomentosa Volk \& Perold, sp. nov., described here, is at first glance somewhat similar to $R$. hirsuta in its habit, hence the earlier confusion in Volk $\&$ Perold (1986). It also resembles $R$. hirsuta in its dorsal covering of long hairs and in the triangular scales apically split into cellular strands. $R$. tomentosa, however, differs from $R$. hirsuta in the spongy (not compact) construction of the thallus and in the spores permanently united in tetrads (not single). It belongs to subgenus Thallocarpus and is the type species of the new section Pannosae.

\section{UITTREKSEL}

Riccia hirsuta (Volk \& Perold 1986) word herbeskryf en herillustreer, aangesien die vroeëre beskrywing en illustrasies op twee verskillende, maar tog ietwat soortgelyke spesies gebaseer was. Die ondersoek van nuwe materiaal van $R$. hirsuta, het getoon dat dit tot subgenus Riccia, seksie Pilifer (Volk 1983) behoort. Seksie Micantes (Volk \& Perold 1986) waarvan dit die tipe-spesie was, word derhalwe onder seksie Pilifer geplaas. $\boldsymbol{R}$. tomentosa Volk \& Perold, sp. nov., hier beskryf, is by die eerste aanblik taamlik soortgelyk aan $\boldsymbol{R}$. hirsuta wat groeivorm betref, vandaar die vroeëre verwarring in Volk \& Perold (1986). Dit toon ook ooreenkoms met $R$. hirsuza in die dorsale bedekking van lang hare en in die driehoekige skubbe wat apikaal in sellulêre stringe verdeel is. $R$. tomentosa verskil egter van $R$. hirsuta in die sponserige (nie kompakte) bou van die tallus en in die spore wat permanent in tetrades verenig is (nie enkel nie). Dit behoort tot die subgenus Thallocarpus en is die tipe-spesie van die nuwe seksie Pannosae.

\section{INTRODUCTION}

When $R$. hirsuta Volk \& Perold (1986), the figures of which are referred to below as 1986, was described, it was assumed that all five specimens then listed under this species, definitely belonged here. Among these specimens, only Oliver 8040 had mature spores. Even though there were some indications that the material was not quite homogeneous, the possibility of another, rather similar species, existing in the same area seemed remote, and it was assumed that all material belonged to one species. During fieldwork by Perold in Namaqualand in September/October 1987 and August/September 1988 and by Oliver in July 1989 , six new collections of densely hairy specimens were made, each one with distinctly papillose spores which on maturity remain in permanent, \pm globular tetrahedral tetrads. These collections belong to a new species, $R$. tomentosa (see below). Fresh gatherings of $R$. hirsuta, also with a dense dorsal hair covering but with single, reticulately ornamented spores were also made, thus providing more material for study.

\section{Riccia hirsuta emend. Volk \& Perold}

Monoica (?), viridi-grisea, mediocris, perennis; frons usque ad $10 \mathrm{~mm}$ longa, $2-4 \mathrm{~mm}$ lata, duplo ad triplo latior

\footnotetext{
* Botanische Anstalten d. Univ. Würzburg D8700, Germany, BRD.

** National Botanical Institute, Private Bag X101, Pretoria 0001.

MS. received: 1989.02 .20 .
}

quam crassa, simplex vel furcata, obcuneata vel oblonga, apice breviter emarginata sparsimque sulcata, antice convexa, in sicco subplana ad concava, dense hirsuta ob pilos longos (inde nomen speciei), marginibus plus minus attenuatis; costa lata, crassa, subplana vel convexa, ad margines sensim excurrens. Stratum aeriferum canalibus aeriferis altis. Squamae grandes, marginem frondis superantes, imbricatae, hyalinae, deltatae, apicibus in filis liberis scissis, vel dentatis. Sporae triangulo-globulares, polares, brunneae, $115-125 \mu \mathrm{m}$ diametro, late alatae, margine subtiliter crenato, imperfecte reticulatae, granulatae; areolae in diametro sporarum 6-8, centrales majorae. Chromosomatum numerus $\mathrm{n}=8$ (Bornefeld 1984).

Thallus monoicous (?), perennial, scattered, not in rosettes, dorsal surface hirsute with thick pelt of shiny hairs (Figure 2A), whitish along margins, greenish grey over centre; medium-sized to large (Figures 1A, C; 1986: 1A); branches simple or bifurcate, up to $10 \mathrm{~mm}$ long, $2,0-4,0$ $\mathrm{mm}$ wide, $1,5-2,0 \mathrm{~mm}$ thick, i.e. about once to twice wider than thick; oblong, broadening towards truncate apex (Figure 2B); groove short, soon becoming flat; margins subacute; flanks sloping outwards in a short wing (Figure ID), greyish green, occasionally with some reddish purple flecks; ventral surface slightly rounded to plane, pale green; when dry (Figure 1B), sides partly inflexed, dorsal surface grey, dusty from accumulation of sand grains trapped between hairs. 


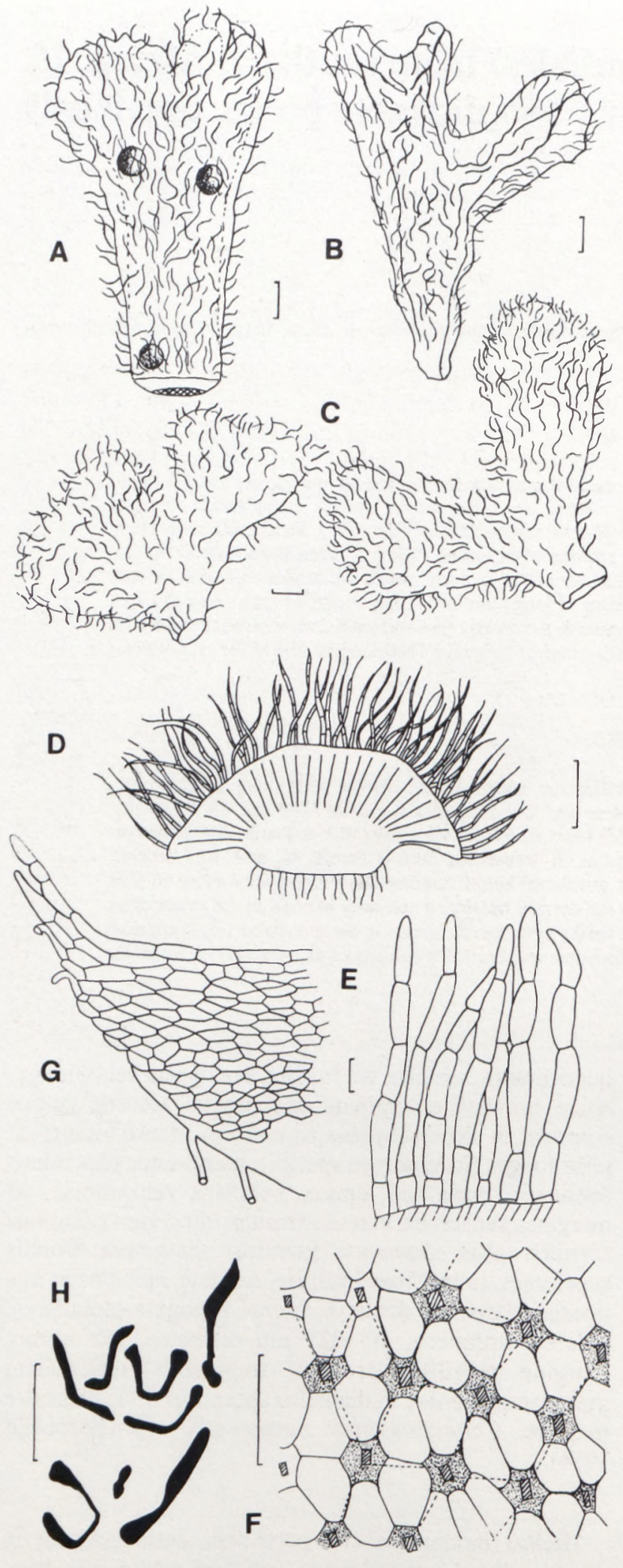

FIGURE 1. - Riccia hirsuta. Morphology and anatomy. A, old thallus with sporangia; B, dry thallus, margins inflexed; C, two young thalli from culture; $\mathrm{D}$, transverse section through mature thallus; E, dorsal hair pillars in transverse section; F, horizontal section at level of stomata (hatched) and basal cells of hairs (hairs omitted) with air canals (stippled) and chlorenchyma also shown; G, scale; H, chromosomes. A, B, H, Oliver 8040 (Type); C, E-G, S.M. Perold 2182; D, Oliver 8038 . A - G by Volk; H by Bornefeld. Drawings by J. Kimpton. Scale bars on A-D = 1 $\mathrm{mm} ; \mathrm{E}-\mathrm{G}=100 \mu \mathrm{m} ; \mathrm{H}=1 \mu \mathrm{m}$.

Anatomy: dorsal covering of free-standing, waterrepellent, hyaline, straight to bent, closely packed hair-like cell pillars or filaments of nearly equal length, up to 1200 $\mu \mathrm{m}$ long, occupying up to almost $1 / 2$ the thickness of the thallus (Figure 1D), consisting of four to six elongated, thin-walled cells (Figures 1E, 2C), up to $375 \times 40-100$ $\mu \mathrm{m}$, gradually tapering to an often abruptly bent apex;air pores mostly 4-sided (Figure 2E), but varying from $3-6$-sided, in contact with about four epithelial cells and leading to rather wide $(40-80 \mu \mathrm{m})$, mostly 6 -sided air canals (Figure 1F); assimilation tissue (chlorenchyma) about 300-500 $\mu \mathrm{m}$ thick, almost $1 / 5-1 / 4$, the thickness of thallus; storage tissue about $700 \mu \mathrm{m}$ thick, consisting of polygonal cells, up to $50 \mu \mathrm{m}$ wide; in older resting thalli, sometimes central core filled with fatty oil and starch (Figure 1986: 1C3); rhizoids arising from ventral epidermis and base of scales, hyaline, some smooth and others tuberculate, up to $25 \mu \mathrm{m}$ wide. Scales partly extending above margin of thallus, overlapping apically, triangular (Figures 1G; 2F; 1986: 1E1-3), about $650 \mu \mathrm{m}$ wide at base and up to $1500 \mu \mathrm{m}$ high, hyaline, occasionally with reddish purple cells at base; cells thin-walled, in body of scale up to $\pm 180 \times 50 \mu \mathrm{m}$, oblong-hexagonal, apex dentate, or more usually cells elongated and separating into a few short, variously bent or twisted filaments (Figures 1G; 2F; 1986: 1F1-4). Antheridia flaskshaped, with much elevated necks (Figures 2D; 1986: 1G), hidden by dorsal pillars. Archegonia with purple necks. Sporangia arranged across width of thallus, up to $700 \mu \mathrm{m}$ wide, overlying tissue often tinged with purple, each containing about 650 spores. Spores triangular-globular, polar, deep dull brown to nearly black, semitransparent to opaque, (95-)115-125 $(-130) \mu \mathrm{m}$ in diameter, with wing about $10 \mu \mathrm{m}$ wide, granular, slightly undulating, margin crenulate to somewhat eroded, at angles with a pore or notched (Figures 2H, I; 1986: 3F); distal face reticulate, with 3-5(-6) large central areolae, $25-38 \mu \mathrm{m}$ wide, completely or incompletely subdivided into smaller areolae, about $12,5 \mu \mathrm{m}$ wide, often with a papilla in the middle (Figure $2 \mathrm{H}, \mathrm{I}$ ), occasionally areolae equally wide and then 8-10 across diameter; central ridges thick and high, outer ridges thinner and lower, sometimes extending partly on to wing (Figure 1986: 3C, D); proximal face with triradiate mark distinct, but poorly delineated, each facet irregularly and rarely completely reticulate (Figures $2 \mathrm{G}$; 1986: 3A, B). Chromosome number $\mathrm{n}=8$ (Bornefeld in Volk \& Perold 1986) (Figure 1H).

$R$. hirsuta is extremely rare and only known from the plateau $\mathrm{N}$ of Leliefontein (Figure 3) (altitude $\pm 1500 \mathrm{~m}$ above sea level), in a winter rainfall area with less than $200 \mathrm{~mm}$ rain per annum. It grows in association with other Riccia species, e.g. $R$. limbata Bisch., $R$. bullosa Link ex Lindenb., $R$. cupulifera A.V. Duthie and $R$. schelpei Volk \& Perold, on clayey soil, at a seepage area or in seasonally damp sandy places between small shrublets and Restionaceae.

$R$. hirsuta is distinguished from other species in section Pilifer by the very tall, shiny dorsal cell pillars and by the triangular scales, apically split into filamentous, short, loose, cellular strands.

\section{SPECIMENS EXAMINED}

CAPE. - 3018 (Kamiesberg): Kamiesberg, lower slopes east of Rooiberg, damp ground between and under renoster bushes (-AC), Oliver 7240 p.p. (F; PRE); Kamiesberg plateau, north of Leliefontein, towards 

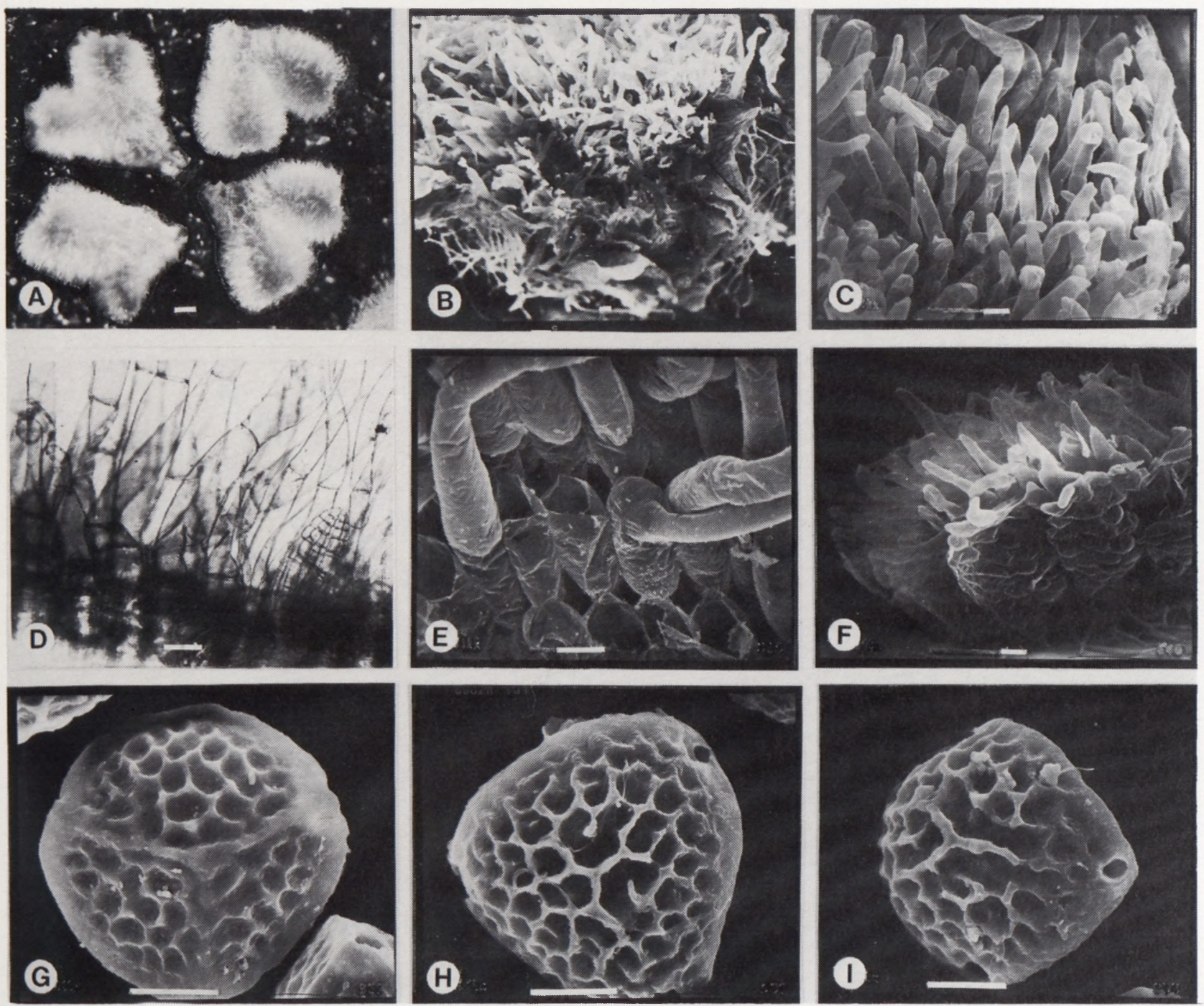

FIGURE 2. - Riccia hirsuta. Morphology and anatomy, spore ornamentation. A, two young thalli; B, apex of thallus from above, densely hairy; C, apices of hair pillars; D, part of transverse section, showing bases of hairs and young antheridial neck; E, two rows of 4-sided air pores, from above, hairs partly removed; $F$, thallus flank with four scales, two central ones with appendages; $G$, proximal face of spore; $\mathrm{H}$, distal face; I, side view of distal face. A, B, D, Oliver 8040 (Type); C, E-I, S.M. Perold 2101. A,D, LM micrographs by Volk; B, C, E-I, SEM micrographs by Perold. Scale bars on $A=1 \mathrm{~mm} ; \mathrm{B}-\mathrm{F}=100 \mu \mathrm{m} ; \mathrm{G}-\mathrm{I}=50 \mu \mathrm{m}$.

Draaiklip,on sandy, periodically moist soil, associated with other Riccia species and Restionaceae, (-AC), Oliver 8038(a), 8040 (PRE, holo.); on road between Kamieskroon and Leliefontein, $5 \mathrm{~km}$ north of Leliefontein, at seepage area (-AC), S.M. Perold 2099-2101; 2182 (PRE).

\section{REJECTION OF SECTION MICANTES VOLK \& PEROLD}

Section Pilifer Volk in Mitteilungen aus der Botanischen Staatssammlung, München 19: 453 (1983). Type species: Riccia albomarginata Bisch. ex Krauss.*

Section Micantes Volk \& Perold in Bothalia 16: 187 (1986). Type species: Riccia hirsuta Volk \& Perold.

$R$. hirsuta, as here emended, agrees in its anatomy and spores with members of the section Pilifer and is therefore placed under that section. Section Micantes, of which it previously was the type species (Volk \& Perold 1986), is now rejected.

* See Perold (1990) [one of the present authors (S.M.P.) is of the opinion that the name $R$. albomarginata has been misapplied since Sim (1926)].
Riccia tomentosa Volk \& Perold, sp. nov.

Dioica (?), pallida, magna, perennis; frondes ad $18 \mathrm{~mm}$ longae, ad $5 \mathrm{~mm}$ latae, ad $4 \mathrm{~mm}$ crassae, late liguliformae,

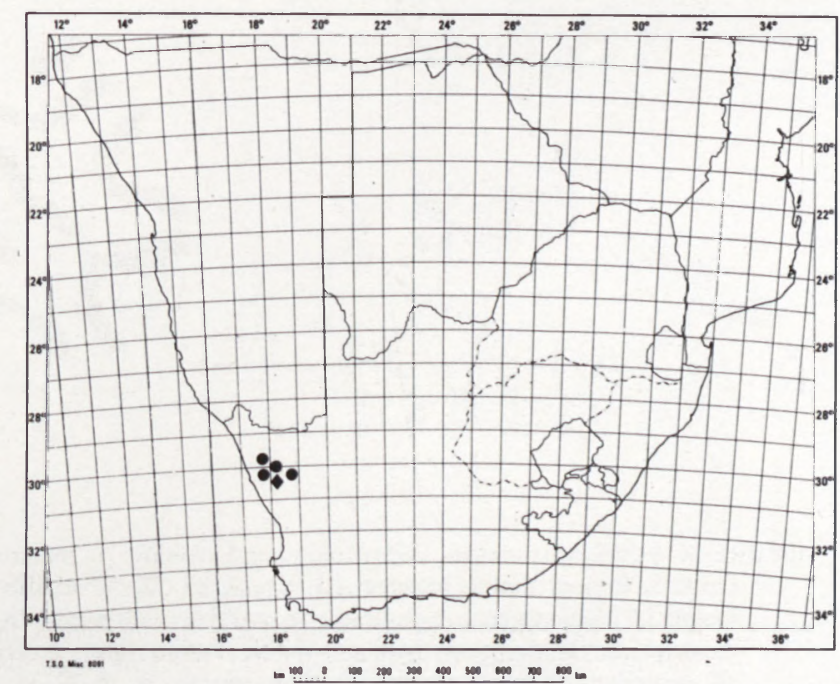

FIGURE 3. - Distribution map of Riccia hirsuta, $\bullet$; and $R$. tomento$s a, O$, in southern Africa. 


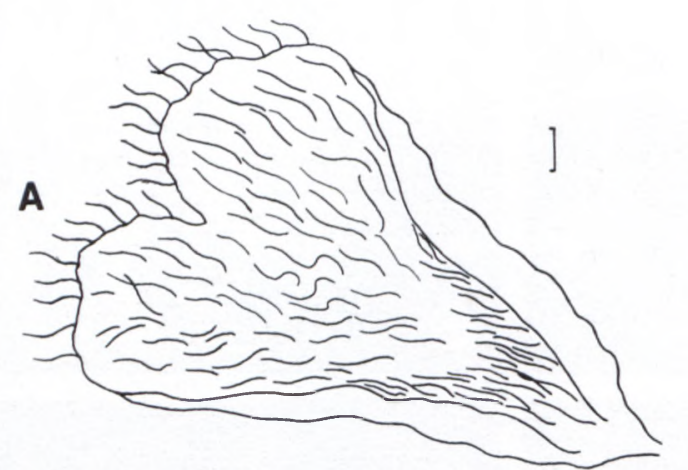

C1
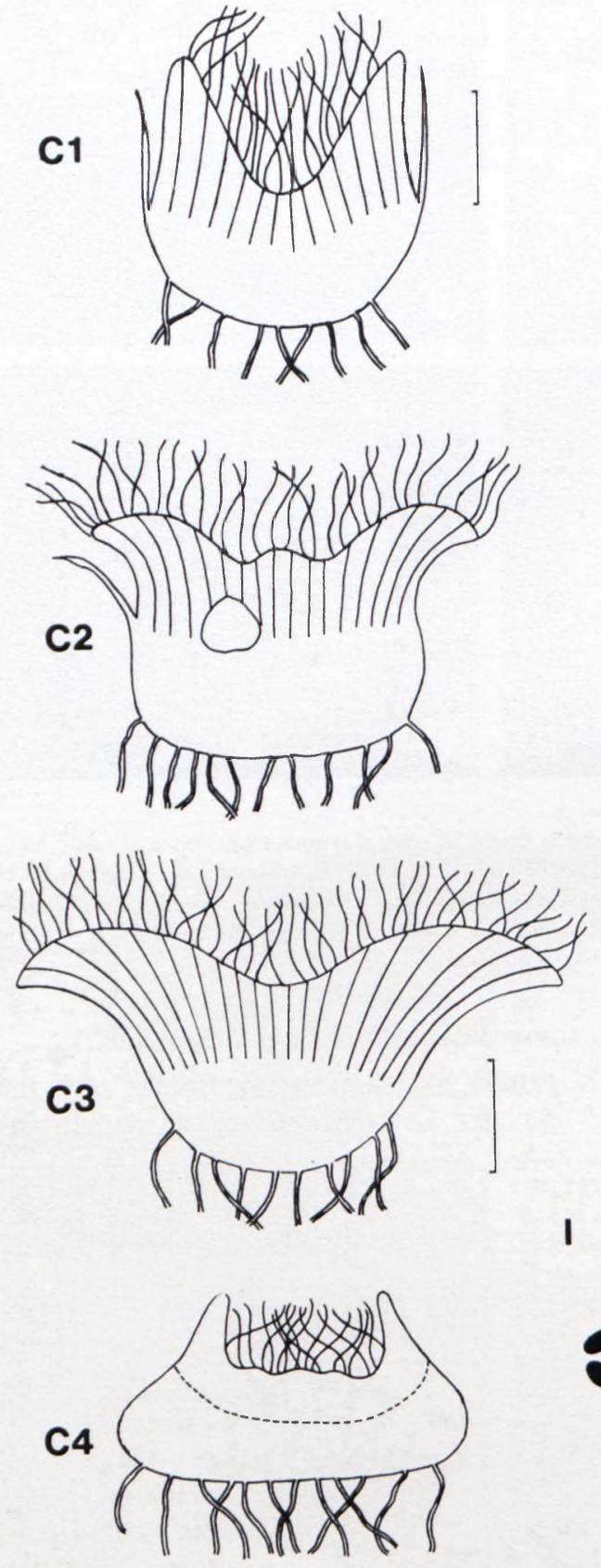

B
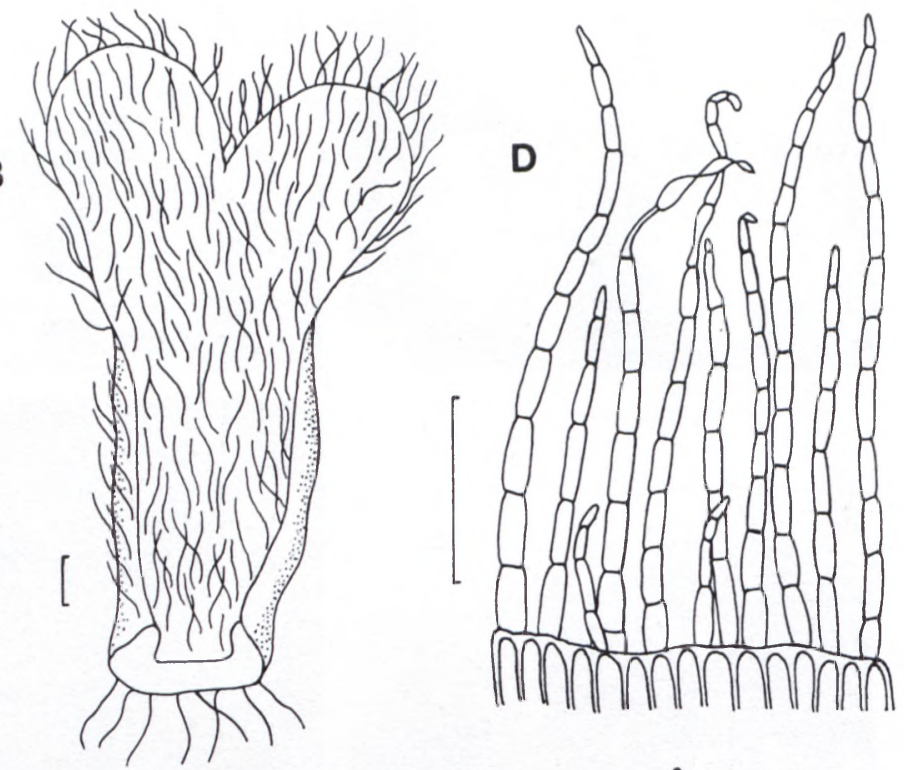

(1)
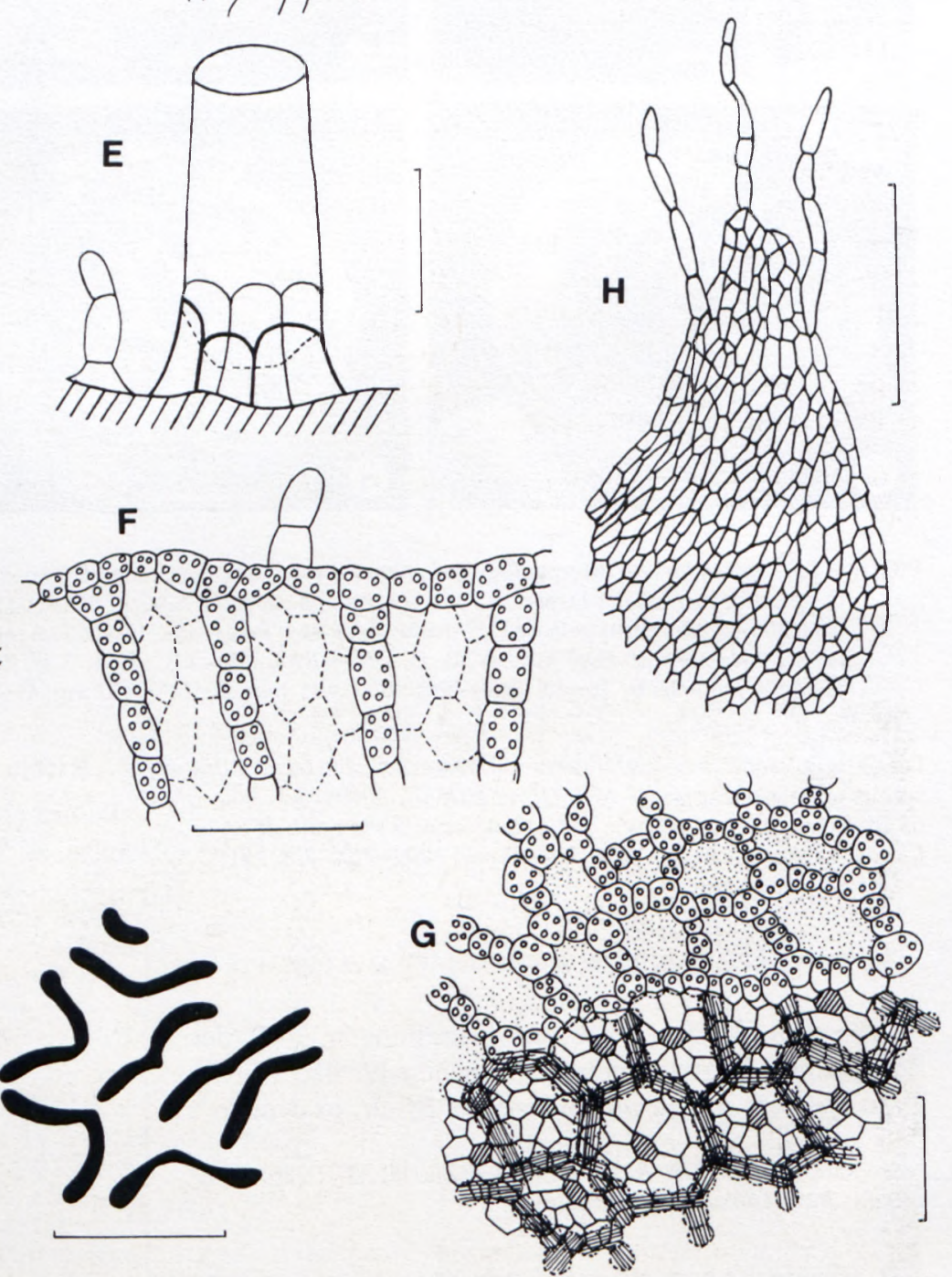

FIGURE 4. - Riccia tomentosa. Morphology and anatomy. A, mature thallus; $\mathrm{B}$, older thallus, flanks inflexed towards base; Cl-4 transverse sections through thallus branches $(\mathrm{Cl}$, near apex; $\mathrm{C} 2, \mathrm{C} 3$ at different distances along length of $\mathrm{B}, \mathrm{C} 4$ through oldest dying part); $\mathrm{D}$, variable sections through thallus branche viewed from below, hence hairs not visible: bottom right, epidermis with stomata (hatched); above, chlorenchyma with lacunae (stippled); H, scale with filaments at apex; I, chromosomes. A, B, C2-4, D-F, H, S.M. Perold \& Crosby 2157; C1, Schelpe 7784; G, S.M. Perold 1495; I, Le Roux \& Fourie PRE-CH4494. A-H by Volk; I by Bornefeld. Drawings by J. Kimpton, after Volk. Scale bars on A-C = $1 \mathrm{~mm} ; \mathrm{D}, \mathrm{H}=500 \mu \mathrm{m} ; \mathrm{E}-\mathrm{G}=100 \mu \mathrm{m} ; \mathrm{I}=1 \mu \mathrm{m}$. 
concavae, simplices vel furcatae, subgregariae vel singulares; pagina superiora in sicco tomentosa (inde nomen) pilis longitudine inaequali usque ad $2700 \mu \mathrm{m}$ longis usque ad 14 cellulis compositis vestita; costa semilunata vel subplana in alas breves excurrens, alae in sicco erectae; stomata distantes, aliquot cellulis circumdata; lacunae aeriferae ad $280 \mu \mathrm{m}$ dilatatae; squamae triangulares, ad $1500 \mu \mathrm{m}$ longae, apicem versus sparsim filamentosae. Sporae in tetradibus tetraedrica globularibus permanenter conjunctae, 100-130-145 $\mu \mathrm{m}$ diametro, sulphureae vel fuscatae, subglobosae, dense papillosae, semiopacae vel opacae. Chromosomatum numerus $\mathrm{n}=$ 8 (Bornefeld 1989).

TYPE. - Cape Province, 3018 (Kamiesberg): Pedroskloof, on road to Rooifontein, $2 \mathrm{~km}$ beyond Willem Stone Bridge, on sandy soil overlying clay (-AA), 1987.09.24, S.M. Perold 1495 (PRE, holo.), associated with other Riccia spp. and Bryum spp.

Thallus dioicous (?), perennial, scattered or in crowded patches, dorsal surface 'shaggy'haired or tomentose (Figure 4A, B; 1986: 1B, 2A), silvery to dusty grey, often with trapped sand particles between hairs; branches large, up to $18 \mathrm{~mm}$ long, simple or bifurcate, segments \pm 12 $\times 2-4-5 \mathrm{~mm}$, narrower toward base (Figure 4C4), oblong to ovate-oblong, apex slightly narrowed, shortly emarginate, groove short and wide, middle part concave, \pm 3-4 mm thick, i.e. almost as wide as thick in section (Figure $4 \mathrm{Cl}$ ), margins raised, obtuse, shortly winged (Figures 4C2, C3; 5B), flanks sloping steeply upward and outward, lower parts occasionally coloured red; ventral face rounded to plane, pale green; when dry, whitish, wide, dorsally deeply concave in centre, wings erect or scarcely inflexed to somewhat reflexed.

Anatomy: dorsal surface covered by free, straight or bent hair-like filaments or pillars (Figures 4D; 5D; 1986: 1D), up to $2700 \mu \mathrm{m}$ long, tapering upwards from a broad base and composed of up to 14 short or elongated thin-walled, hyaline cells of variable length and thickness (Figure 5E), often supported by slightly raised epidermal cells (Figure 4E, 1986: 2D); air pores circumscribed by several (5-7) radially arranged, wedge-shaped cells (Figures 4G; 5F; 1986: 2G, H); assimilation tissue (chlorenchyma) \pm 500 $\mu \mathrm{m}$ thick, $1 / 8-1 / 6$ the thickness of thallus, with sloping, elongated, polygonal air chambers or lacunae up to 280 $\mu \mathrm{m}$ wide (Figures 4F; 1986: 2E), 37-62(-112) $\mu \mathrm{m}$ wide, longest and widest in wings (Figure 5C3) surrounded by isodiametric cells in plates, one cell thick and up to 20 cells high; storage tissue $\pm 500-600 \mu \mathrm{m}$ thick, $1 / 8-1 / 6$ the thickness of thallus, cells angular, up to $50 \mu \mathrm{m}$ wide, with small spaces between. Rhizoids arising ventrally and from base of scales, forming a thick mat, some smooth, mostly tuberculate, $12-25 \mu \mathrm{m}$ wide. Scales triangular, large, up to $1500 \mu \mathrm{m}$ long and base $1250 \mu \mathrm{m}$ wide, hyaline, often red at base, apically with filaments up to $1000 \mu \mathrm{m}$ long (Figure 4H; 1986: 2F), cells in body of scale 5-sided, walls straight to slightly sinuous, up to 112 $\times 25-42 \mu \mathrm{m}$, smaller at base, $62 \times 40 \mu \mathrm{m}$; at one side of scale, a row of rectangular cells, up to $180 \times 40 \mu \mathrm{m}$. Antheridia and archegonia difficult to see, as obscured by dense dorsal hairs. Sporangia bulging dorsally, \pm 800 $\mu \mathrm{m}$ wide, each containing \pm 300 spore tetrads. Spores thick-walled, permanently united in tetrads (Figure 6A, $\mathrm{B}, \mathrm{E}, \mathrm{F}), 116-131-145 \mu \mathrm{m}$ in diameter, pale yellow to ferruginous brown, thickly beset with papillae or verruculae, 3-5 $\mu \mathrm{m}$ wide and projecting as much, obtuse or truncate, arising from nodes of scarcely visible (Figure 6C), to obvious reticulum (Figure 6D). Chromosome number $\mathrm{n}=8$ (Bornefeld 1989).

$R$. tomentosa is endemic and rare, as it has only been found at a few localities in Namaqualand (Figure 3), at altitudes of 1000-1200 m above sea level, with winter
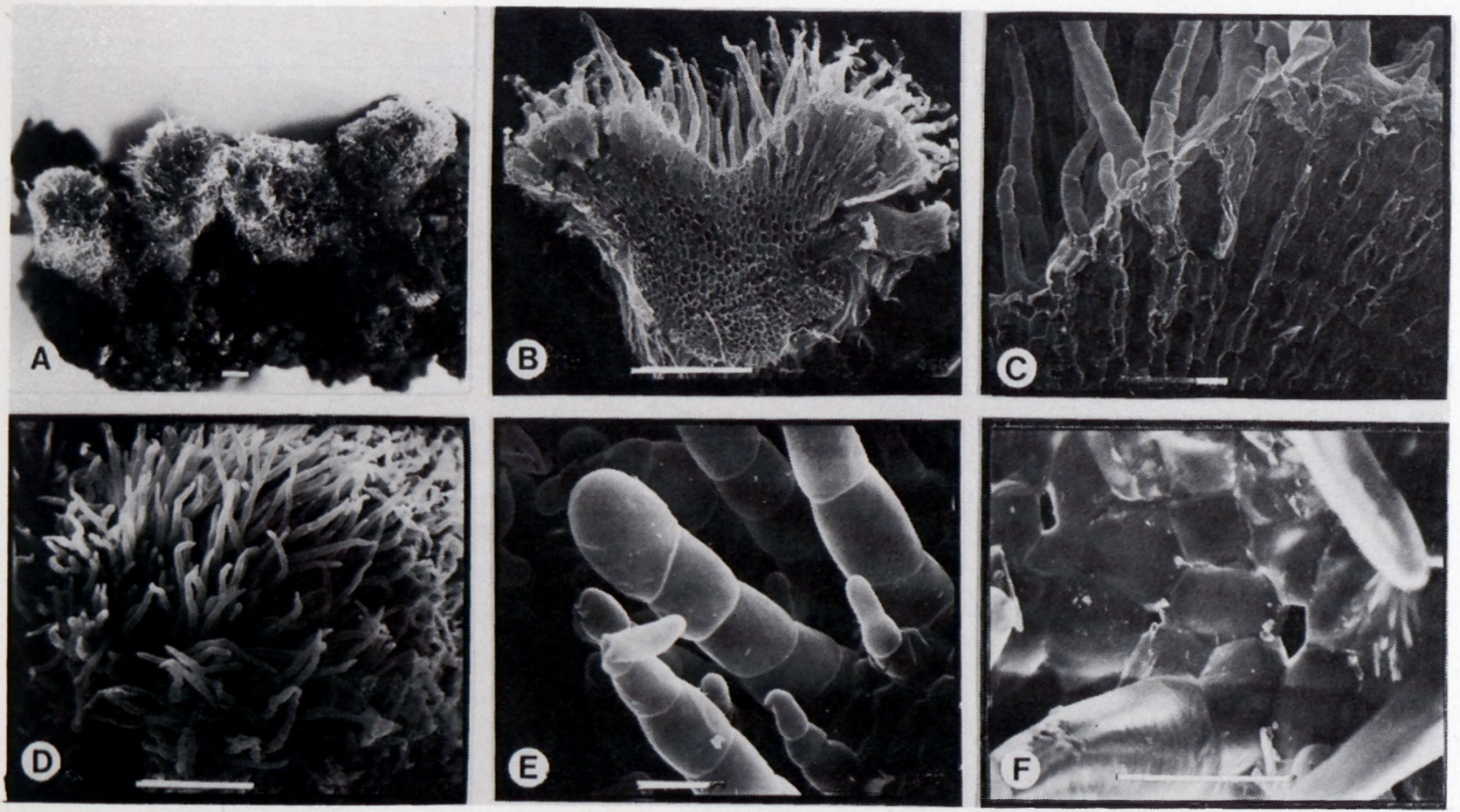

FIGURE 5. - Riccia tomentosa. Morphology and anatomy. A, two young thalli; B, transverse section through thallus branch; C, transverse section through wing with wide lacunae; D, hairs from above; E, variable sizes of dorsal hairs; F, epidermis with air pores. A, S.M. Perold \& Crosby 2157; B-D, S.M. Perold 1556; E, S. M. Perold 1495; F, Le Roux \& Fourie PRE-CH4494. A, by A. Romanowski; B-E, SEM micrographs by S.M. Perold. Scale bars on A, B, D = $1 \mathrm{~mm} ; \mathrm{C}, \mathrm{E}, \mathrm{F}=100 \mu \mathrm{m}$. 
rainfall of less than $200 \mathrm{~mm}$ per annum. It grows on reddish brown, sandy soil, overlying clay, at $\mathrm{pH}$ values 5,$6 ; 6,6 ; 6,8$ and 7,5 , in open areas and in association with Bryum argenteum Hedw. Its distribution is sympatric with that of $R$. hirsuta.

$R$. tomentosa is dorsally tomentose, hence the specific epithet, and differs from other southern African Riccia species, e.g. $R$. hirsuta (Table 1), by the unique hair-like outgrowths from many of the epidermal (not epithelial) cells and by the papillose to verruculose tetrad spores. It shares large triangular scales, apically splitting into filamentous cellular strands with $R$. hirsuta.

\section{SPECIMENS EXAMINED}

CAPE. - 2917 (Springbok): Hester Malan Res., Carolusberg N, at gate on western boundary (-DB), Le Roux \& Fourie PRE-CH4494 (PRE); Schelpe 7784 (BOL, PC, PRE). 3017 (Hondeklipbaai): Arkoep area, 15 km N of Kamieskroon, road towards Brakwater, sandy clay flats, open ground (-BB), Oliver 9196, 9197 (PRE). 3018 (Kamiesberg): 18 km NE of Kamieskroon on road to Rooifontein, at rock outcrop, on soil (-AA), Perold \& Reid 1462 (PRE); 4 km on road to Rooifontein, after turnoff from Kamiesknoon/Leliefontein road, sandy soil (-AA), Perold \& Crosby 2157, 2158 (PRE); Pedroskloof, on road to Rooifontein, $2 \mathrm{~km}$ beyond Willem Stone Bridge (-AA), S.M. Perold 1495 (PRE, holo.); 29 km SE from Platbakkies on road to Kliprand, Farm Banke, rock outcrops, sandy soil (-BC), S.M. Perold 1556 (PRE). Vogel C5446 (MJG), Nuwefontein, Hondeklipbaai, may belong here, but its identity is uncertain as it is sterile).

Among the species of Riccia presently known, $R$. tomentosa occupies a unique position as it has both primitive and derived characters. The spores of subgenus Thallocarpus which remain in tetrads, are regarded as primitive (Jovet-Ast 1987), as are also the 'loose' construction of the assimilation tissue with wide lacunae, and the chlorophyllose epidermis which is pierced by air pores (stomata) that are circumscribed and separated by a ring of cells. Regarded as derived characters are the hairy covering of the dorsal surface of the thallus (similar to that in the section Pilifer, subgenus Riccia) and the raised basal cells of the larger hairs.

\section{SECTION PANNOSAE}

Pannosae Perold, sect. nov., subgen. Thallocarpus (Lindb.) Jovet-Ast. Sporae permanenter conjunctae in tetradibus; thallus dorsaliter pannosus ob pilos longos (inde nomen).

Ripe spores permanently united in tetrads; thallus dorsally felt-like (pannosus) because of long hairs.

TYPE. - R. tomentosa Volk \& Perold.

Pannosae is a new section of subgenus Thallocarpus. $\boldsymbol{R}$. tomentosa is the type species and only known species of this new section, which is characterized by spores permanently joined together in tetrads, as in other members of subgenus Thallocarpus (Lindb.) Jovet-Ast, but differs from all hitherto known species of this subgenus by a thick felt-like (Lat. pannosus) covering of very long, multicellular hairs.

\section{CORRECTION OF PUBLISHED ILLUSTRATIONS}

The existence of two similar-looking species, in the same area, regrettably gave rise to mistakes not only in the naming of the specimens, but also in the illustrations (Volk \& Perold 1986). Specimens from both species were used for Figures 1 and 2 (pp. 188 \& 189). For Figures 1B, H and 2A-H, Le Roux \& Fourie PRE-CH4494 was used and for Figure 1D, Schelpe 7784; these two specimens were collected from the same population, and are $R$. tomentosa; firstly, because the air pores are distant and secondly, because the spores from Schelpe 7784, though immature and diseased, nevertheless suggest that the ornamentation
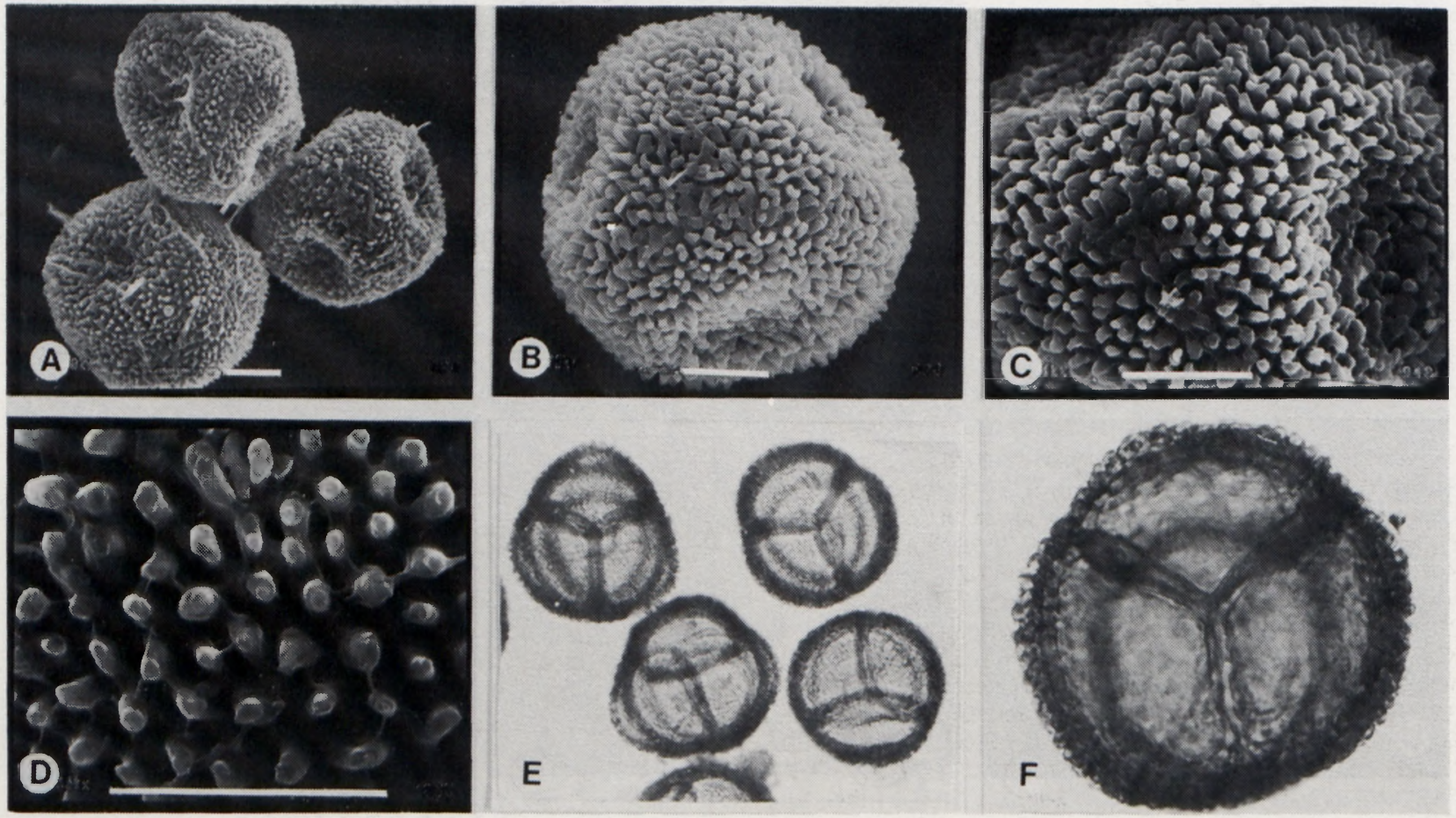

FIGURE 6. - Riccia tomentosa. Spores. A, three tetrads; B, one tetrad; C, join mostly hidden by tubercles; D, reticulum between tubercles; E, F, tetrads. A, E, S.M. Perold 1556; B, C, F, S.M. Perold 1495; D, S. M. Perold \& Crosby 2157. A-D, SEM micrographs by S.M. Perold; E, F, LM micrographs by Volk. Scale bars on A-D $=50 \mu \mathrm{m}$; width of tetrads on $E, F= \pm 125 \mu \mathrm{m}$. 
TABLE 1.-Differences between $R$. hirsuta and $R$. tomentosa

\section{R. hirsuta}

R. tomentosa

1. spores single; ornamentation reticulate

2. hairs of dorsal covering crowded, \pm equally long

3. base of hairs without supporting cells

4. epithelium with unspecialized air pores closely spaced, each epithelial cell in contact with several air spaces

5. air canals short, fairly wide

6. thallus medium-sized, dorsally flat to \pm convex

7. found in exposed locality at seepage, or in light shade at area under shrublets could be papillate to tuberculate. Unfortunately, these clues were subsequently ignored, when examining Oliver 8040 (the type specimen of $R$. hirsuta Volk \& Perold emend.), which has very crowded dorsal hairs and mature, triangular-globular spores with \pm incomplete reticulate ornamentation on both faces, as illustrated in Figure $3 \mathrm{p}$. 190 (Volk \& Perold 1986).

The captions should accordingly be corrected as follows: for Figure 1, $R$. hirsuta A, C1-3, E1-3, F1-4, G (Oliver $8040,8038 b)$; $R$. tomentosa B, H (Le Roux \& Fourie PRECH4494); D, Schelpe 7784; and for Figure 2, R. tomentosa (not R. hirsuta) Le Roux \& Fourie PRE-CH4494.

\section{ACKNOWLEDGEMENTS}

The authors wish to thank Dr habil. T. Bornefeld, Am Reele 1, D-8706, Höchberg, W Germany for the chromosome counts and figures and the Curator of BOL, University of Cape Town for the loan of the late Prof. E.A. Schelpe's specimen. Sincere thanks to Dr E.O. Campbell, Massey University, New Zealand and Dr E.W. Jones, Oxford, for reading the manuscript and for their valuable criticism.

\section{REFERENCES}

BORNEFELD, T. 1989. The Riccia species of S and SW Africa. Chromosome numbers and composition of the chromosome sets. Nova Hedwigia 48: 371-382. spores in tetrads; ornamentation papillate

dorsal hairs spaced, of variable length

base of some hairs with raised supporting cells

epidermis with well-spaced stomata, radially circumscribed by 5-7

wedge-shaped cells; some cells without contact with air pores

air chambers long, wide, sloping

thallus large, concave dorsally

found in fully exposed localities in sandy, drier areas
JOVET-AST, S. 1975. Précisions sur les caractères de deux Riccia du sous-genre Thallocarpus. Revue Bryologique et Lichénologique 41: 449-456.

JOVET-AST, S. 1987. Vers une classification phylogénétique des espèces du genre Riccia. The Bryologist 90: 321-330.

KRAUSS, F. 1846. Pflanzen des Cap- und Natal-Landes, gesammelt von Dr. Ferdinand Krauss. Flora 29: 135, 136.

PEROLD, S.M. 1989. Spore-wall ornamentation as an aid in identifying the southern African species of Riccia (Hepaticae). Journal of the Hattori Botanical Laboratory 67: 109-201.

PEROLD, S.M. 1990. Studies in the genus Riccia (Marchantiales) from southern Africa. 16. $R$. albomarginata and $R$. simii sp. nov. Bothalia 20: 31-39.

SIM, T.R. 1926. The bryophyta of South Africa. Transactions of the Royal Society of South Africa 15: 1-475.

VAN ZINDEREN BAKKER, E.M. 1956. South African pollen grains and spores. Part II: 61-132. Balkema, Amsterdam.

VOLK, O.H. 1981. Beiträge zur Kenntnis der Lebermoose (Hepaticae) aus Südwestafrika (Namibia). II. Mitteilungen aus der Botanischen Staatssammlung, München 17: 245-252.

VOLK, O.H. 1983. Vorschlag für eine Neugliederung der Gattung Riccia L. Mitteilungen aus der Botanischen Staatssammlung, München 19: $453-465$.

VOLK, O.H. 1988. $R$. crenatodentata (Marchantiales) sp. nov. aus Arabien. Studien über Bryophyten aus Arabien 11. Nova Hedwigia 46: 27-35.

VOLK, O.H. \& PEROLD, S.M. 1986. Studies in the genus Riccia (Marchantiales) from southern Africa. 6. R. hirsuta, a new species in a new section. Bothalia 16: 187-191. 